\title{
ADSORPTION OF OLIGOMERIC PEROXIDES ON AEROSIL AND MAGNESIUM OXIDE AND THEIR BEHAVIOR ON THE WATER-AIR PHASES INTERFACE
}

\author{
Volodymyr Dutka ${ }^{1,}$, Nataliya Oshchapovska ${ }^{1}$
}

https://doi.org/10.23939/chcht15.01.047

\begin{abstract}
Oligomeric peroxide adsorption of sebacic acid on aerosil and magnesium oxide was studied. Adsorption process parameters were found. It is shown that the adsorption takes place through the hydrogen bonds formation between $\mathrm{OH}^{-}$groups of adsorbents surface and peroxide groups. The adsorption process suggests the behavior of peroxide compounds on the water-air phase's interface. Monomolecular film formations on water surface for oligomeric peroxides were studied. It was found that calculated values of the area extrapolated to zero pressure $\left(S_{0}\right)$ depend on the solvent which was used to apply the peroxide in the phases interface. Oligomeric peroxide monolayers considered as condensation-type monolayers. Thermal decomposition of oligomeric peroxide and its di- and monoperoxide analogues was studied. It was shown that total constants of thermal degradation rate $k$ for oligomeric peroxide are higher than those for di- and monoperoxide analogues. There is a correlation between $S_{0}$ calculated values and the constants of thermal degradation rate for oligoperoxide. The less is $S_{0}$ value the higher is $k$ value. The conformational state of the macromolecule was preserved during transferring the oligomeric peroxide solution in an organic solvent to the phases interface that affects $k$ values.
\end{abstract}

Keywords: oligomeric peroxides, adsorption, monolayer, reactivity.

\section{Introduction}

Oligomeric peroxide considered as effective initiators of radical polymerization [1-4]. The initiators of this type compounds can be used to obtain polymermineral composites, process the surfaces of different nature or modify polymeric materials. The adsorption of a monomer and initiator on solid surface is affected by the

\footnotetext{
${ }^{1}$ Ivan Franko National University of Lviv,

6, Kyryla and Mefodia St., 79005 Lviv, Ukraine

vdutka@ukr.net

(c) Dutka V., Oshchapovska N., 2021
}

processes involving oligomeric peroxides in the presence of dispersed minerals.

The introduction of dispersed oxides $\mathrm{Fe}_{2} \mathrm{O}_{3}, \mathrm{Cr}_{2} \mathrm{O}_{3}$ and $\mathrm{V}_{2} \mathrm{O}_{5}$ into the polymerization mixture affects the thermal decomposition rate of radical polymerization initiators [5]. The destruction of peroxide occurs in both a homogeneous solution and surface of the disperse oxides. Initiator heterolysis might be possible depends on the surface nature. The polymerization rate of the peroxide heterogeneous decomposition on the surface of dispersed mineral decreases in comparison with that of the homogeneous system. The oxidation-reduction interaction of peroxide-surface with dispersed mineral leads to an increase in the polymerization process rate. The nature of the dispersed oxide, apart from the effect on the thermal destruction rate of the peroxide initiator, affects the growth and breakage of the polymer chains. It suggests on the features that will be manifested for aerosil and magnesium oxide. Because of unique properties aerosil and magnesium oxide are often used to produce polymermineral composites [6-8]. When the mineral was added to the polymerization system, adsorption of both monomer and peroxide initiator was observed [9]. This feature affects the basic parameters of polymerization and the molecular characteristics of polymers which formed in the filled systems. Aerosil and dispersed oxides $\mathrm{Fe}_{2} \mathrm{O}_{3}, \mathrm{Cr}_{2} \mathrm{O}_{3}$, $\mathrm{V}_{2} \mathrm{O}_{5}, \mathrm{PbO}$ and natural mineral clinoptilolite can affect both the rate of polymerization process and the thermal decomposition of the peroxide initiator [10-13]. Investigated disperse minerals influence on molecular weights of polymers and molecular weights distribution [12-14]. In the presence of disperse minerals, a linear breakage of the growing polymeric radicals with the participation of surface groups of the filler is observed. Surface modification with the dispersed oxide $\mathrm{TiO}_{2}$ changes the polymerization rate and affects the rate constant of the peroxide thermal decomposition [15]. In the case of polymerization in the presence of disperse minerals, grafting of polymer macromolecules with the filler surface is observed. The degree of macromolecules grafting with the minerals surface depends on the nature 
of the filler and initiator of radical polymerization. Consequently, the nature of disperse minerals surface affects the course of the polymerization process and the properties of polymer-mineral composites, where adsorption of all components plays important role.

So, the aim of this work was to study adsorption of oligomeric peroxide of sebacic acid (OSA) on aerosil and magnesium oxide and their behavior on the water-air phases interface. The peculiarities of the formation of monomolecular layers of oligomeric peroxides of pumelinoic (OPA), azelaic (OAA) and sebacin OSA acids on the water surface were studied.

\section{Experimental}

Oligomeric peroxides were obtained by the polycondensation reaction on the phases interface of the corresponding dibasic acids chloride and sodium peroxide [16]. The degree of the polycondensation of oligomeric peroxides was within the range of 9-20. The oligomeric peroxides of sebacic (OSA), azelaic (OAA) and pimelic (OPA) acids were studied in this work. To compare the rate constants of the thermal decomposition, the monoand diperoxide analogues of oligoperoxide were obtained $[17,18]$. The adsorption experiments were carried out for a styrene solution, which was released from the inhibitor and fractionated before adsorption experiments. Commercial samples of aerosils (A-175, alumino aerosil (AlA), titanone aerosil (TIA) and methyl aerosil (MeA)) were used in the experiments.

Specific surface area for A-175, AIA, TIA and MeA were determined with a low-temperature adsorption of gaseous nitrogen and their correspondent values were $\sim 190,170,120$ and $190 \mathrm{~m}^{2} / \mathrm{g}$, respectively. The size of the filler particles was in the range of $10-40 \mathrm{~nm}$ with the bulk density of $40-60 \mathrm{~g} / \mathrm{l}$. The content of aluminum oxide was $3.5 \%$ and titanium oxide $-40.3 \%$ in AIA and TIA, respectively. Methyl aerosil contained $4.0 \%$ of methoxyl groups. Magnesium oxide (MERCS, 99.5\%) with a specific surface area of $40 \mathrm{~m}^{2} / \mathrm{g}$ was used in adsorption experiments. OSA adsorption on aerosils and magnesium oxide were carried out in a solution of styrene. Adsorption experiments were carried out in the temperature range of 308-318 K. The OSA solution of known concentration was added to an ampoule containing a certain amount of aerosil, then purged in argon and sealed. During the experiments the ampoules were continuously rotated. After that, the ampoules were removed from thermostat, open and centrifuged. The content of peroxide groups in styrene was determined with the iodometric method [19].

The Langmuir vertical balance was used for the measurement of the monolayers surface pressure of the peroxides. Solutions of peroxides were applied on a water surface of a cuvette in size of $60 \times 16.5 \mathrm{~cm}$. A barrier made of teflon compressed the monolayer on the water surface. All measurements were carried out at a compressive rate of $0.1 \mathrm{~cm} / \mathrm{s}$. To obtain a monomolecular layer, a drop of peroxide solution in an organic solvent was applied to a pure aqueous surface. The monolayer was compressed after $10 \mathrm{~min}$. Water surface was renovate using the teflon barrier before every monolayer preparation. Measurement of monolayers surface pressure in different solvents was carried out 3-4 times at $293 \mathrm{~K}$. In all cases, calculation error at the determination of the area value extrapolated to zero pressure did not exceed \pm 5 rel $\%$.

The thermal decomposition of oligomeric peroxides in organic solvents was investigated in a sealed ampoule. A solution of peroxide of a certain concentration in the solvent was placed in a clean and dry ampoule and was purged with argon before to be sealed. The ampoules were thermostated at temperature value of $353 \pm 0.05 \mathrm{~K}$. At certain time intervals, the ampoules were chilled and peroxide concentration was determined by the iodometric method [19]. All organic solvents were thoroughly purified through their fractionation in argon atmosphere $[20,21]$. Calculation errors at the determination of the thermal decomposition constants did not exceed $3 \%$.

\section{Results and Discussion}

Adsorption of OSA on aerosils and $\mathrm{MgO}$ is well described by the well-known equation of Langmuir. The adsorption isotherms of OSA on magnesium oxide at various temperatures are shown in Fig. 1.

The obtained data for the adsorption are linear in the $1 / C-1 / A$ coordinates (Fig. 2), which allowed to determine the parameters of the adsorption process: the maximum adsorption $\left(A_{\infty}\right)$, the adsorption-desorption equilibrium constant $(K)$, and the area of the oligoperoxide link in the adsorption layer $(S)$.

The $\Delta G, \Delta H$ and $\Delta S$ values of the adsorption process were calculated by the temperature dependence of the adsorption constants (Table 1). The thermodynamic parameters of the adsorption processes on the surface of aerosil and magnesium oxide are similar. The area of the peroxide layer is $\left(61-53 \AA^{2}\right)$ on aerosil surface and (13.7$11.5 \AA^{2}$ ) on $\mathrm{MgO}$ surface. The different numerical values of $S$ on aerosil and magnesium oxide surface may indicate different orientation of OSA macromolecules in the adsorption layer. Adsorption of OSA occurs due to the formation of hydrogen bonds between peroxide groups and $\mathrm{OH}^{-}$groups on the surface of the aerosil and $\mathrm{MgO}$. Since number of $\mathrm{OH}^{-}$groups on the methyl-aerosil surface is very low the OSA adsorption is negligible (Table 1). 


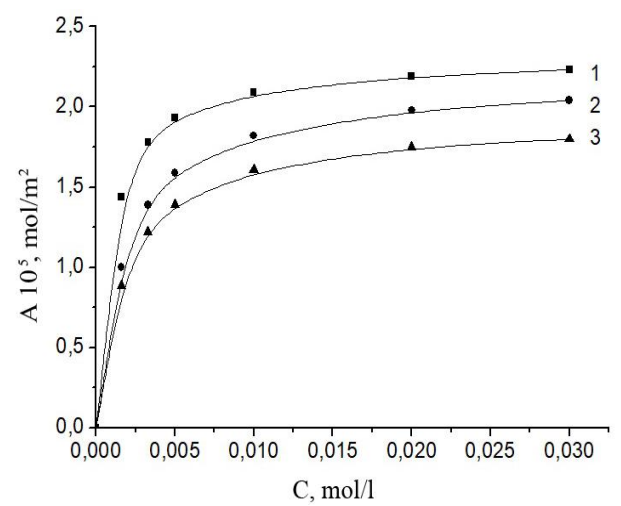

Fig. 1. Isotherms of OSA adsorption on magnesium oxide at $308 \mathrm{~K}(1) ; 313 \mathrm{~K}(2)$ and $318 \mathrm{~K}(3)$. Styrene is a solvent

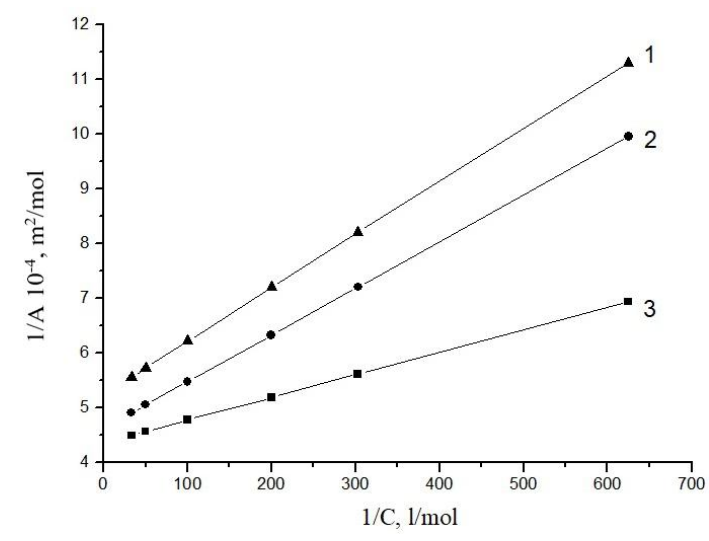

Fig. 2. The dependence of $1 / A$ on $1 / C$ for the process of OSA adsorption on magnesium oxide at $318 \mathrm{~K}(1) ; 313 \mathrm{~K}(2)$ and $308 \mathrm{~K}$ (3). Styrene is a solvent

Table 1

Physico-chemical parameters of OSA adsorption on the aerosils and magnesium oxide surfaces

\begin{tabular}{|c|c|c|c|c|c|c|c|}
\hline Adsorbent & $T, \mathrm{~K}$ & $A_{\infty} \cdot 10^{6}, \mathrm{~mol} / \mathrm{m}^{2}$ & $S 10^{20}, \mathrm{~m}^{2}$ & $K_{p}, \mathrm{~m}^{3} / \mathrm{kmol}$ & $-\Delta G, \mathrm{~kJ} / \mathrm{mol}$ & $-\Delta H, \mathrm{~kJ} / \mathrm{mol}$ & $-\Delta S, \mathrm{~J} / \mathrm{mol} \mathrm{K}$ \\
\hline Aerosil A175 & 308 & 3.10 & 53 & 871 & 17.3 & \multirow{3}{*}{50.2} & \multirow{3}{*}{107} \\
\hline Aerosil A175 & 313 & 2.99 & 56 & 529 & 16.3 & & \\
\hline Aerosil A175 & 318 & 2.74 & 61 & 421 & 16.0 & & \\
\hline Aerosil AAl & 313 & 1.99 & 84 & 576 & 16.5 & - & - \\
\hline Aerosil ATi & 313 & 1.14 & 146 & 221 & 14.0 & - & - \\
\hline Aerosil AMe & 313 & 0.29 & 572 & 28 & 8.76 & - & - \\
\hline $\mathrm{MgO}$ & 308 & 22.9 & 13.7 & 1059 & 17.8 & \multirow{3}{*}{55.1} & \multirow{3}{*}{121} \\
\hline $\mathrm{MgO}$ & 313 & 21.6 & 13.0 & 543 & 17.2 & & \\
\hline $\mathrm{MgO}$ & 318 & 19.1 & 11.5 & 533 & 17.0 & & \\
\hline
\end{tabular}

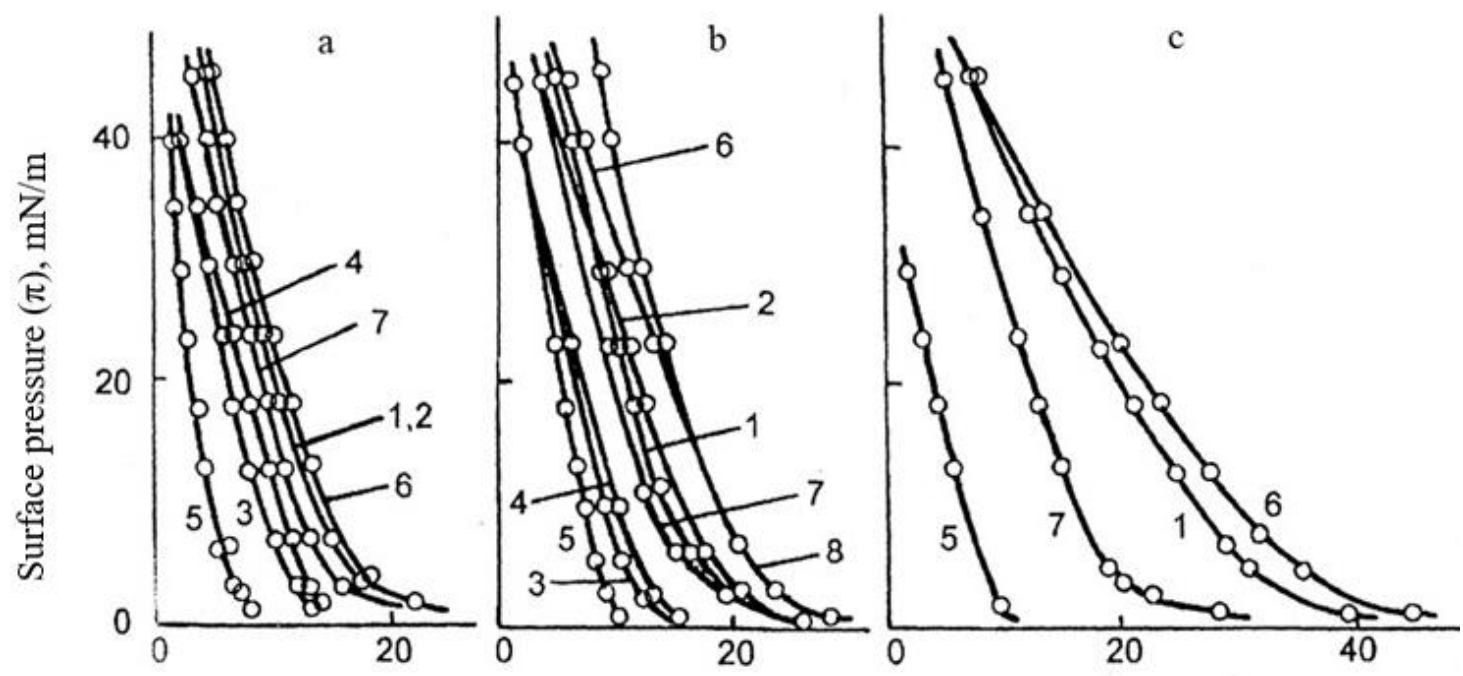

Area of the monomer link Sm, $\AA^{2}$

Fig. 3. The isotherms of surface pressure $(\pi)$ of monolayers of OPA (a), OAA (b) and OSA (c) oligomeric peroxides. Solvents are benzene (1); toluene (2); acetone (3); methylethylketone (4); dioxane (5); chloroform (6); chlorobenzene (7); ethylbenzene (8) and ethylacetate (9) 
The adsorption processes of peroxide on aerosil and magnesium oxide surface are similar. The adsorption of peroxide groups occurs due to the formation of hydrogen bonds with $\mathrm{OH}^{-}$groups of aerosil or magnesium oxide surface.

The structure of the OPA macromolecules in the adsorption layer may be similar to the behavior of oligoperoxide in the monomolecular layer at the water-air phases interface. The method of studying monomolecular layers has been successfully used to study polymers layers $[22,23]$. The nanomaterials were constructed based on monomolecular layers of proteins [24]. Interesting data were obtained in the study of polymeric monomolecular films containing xanthene groups [25]. The value that correspond to the monomeric chain of peroxide in a monolayer $\left(S_{\mathrm{m}}\right)$ grows in direction of OPA $<\mathrm{OAA}<\mathrm{OSA}$. The isotherms of surface pressure $(\pi)$ of the studied oligomeric peroxides are shown in Fig. 3. The monolayers of the studied oligomeric peroxides belong to the condensation-type monolayers [26].

Higher size of methylene bridge between peroxide groups leads to the shift of the isotherms towards larger area of the monomer link values $\left(S_{\mathrm{m}}\right)$ (Fig. 3). The $S_{\mathrm{m}}$ value is influenced with the nature of the solvent used to form monolayer on the phases interface. The oligomeric peroxides in various solvents are in different conformation states which might be preserved when transferred to a pure water surface. Different conformations of oligomeric peroxide, depending on the solvent, are correlated with the surface pressure isotherms and on the surface area $S_{\mathrm{m}}$.

The influence of the solution concentration on the surface pressure of oligoperoxides was studied using OPA and OAA. Benzene, styrene and chloroform were used as solvents. The concentration of peroxide varied from 0.04 to $1.0 \mathrm{~g}$ per $100 \mathrm{ml}$. The surface pressure isotherms of OPA monolayers, which were formed on the surface of water from benzene solutions are shown in Fig. 4. The nature of the surface pressure isotherms for OAA is almost the same. The solvent used to apply peroxide to the

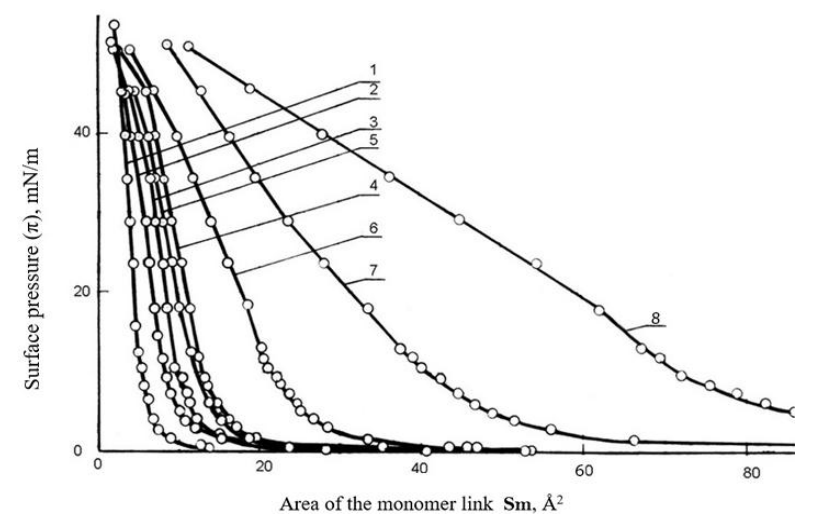

Fig. 4. The isotherms of OPA surface pressure when applying a monolayer from benzene solution of various concentrations $(\mathrm{g} / \mathrm{dl})$ : 1.0 (1); 0.55 (2); 0.32 (3); 0.25 (4); 0.16 (5); 0.125 (6); 0.08 (7) and $0.04(8)$. Temperature is $298 \mathrm{~K}$ surface affects the values of area corresponding to the monomer link. It can be concluded that a decrease in the concentration of oligomer peroxide leads to a shift of the surface pressure isotherms towards higher values of the areas corresponding to the monomeric link of OPA. Various types of films from stretched-liquid to condensedliquid ones can be obtained [20]. The numerical values of the areas that belong to the monomeric peroxide layer $\left(S_{\mathrm{m}}\right)$ for the films obtained from the applying solutions of different concentrations are given in Table 2. An increase in the size of the monomer chain on $-\mathrm{CH}_{2}-$ group for OAA leads to the increase in the numerical values of $S_{\mathrm{m}}$ compared to that of OPA. The values of $S_{\mathrm{m}}$ for films formed from chloroform are slightly higher than the corresponding values obtained from benzene or styrene solutions (Table 2). This indicates a higher thermodynamic quality of chloroform in comparison with benzene or styrene. The extrapolated values of the $S_{\mathrm{m}}$ areas that belong to the monomer unit are related to the volume of the oligoperoxide coil in the solution. The transfer of oligomeric peroxide macromolecules to the surface of water largely retains the conformational state of peroxide and affects the reactivity of peroxide groups.

The correlation of $S_{0}$ values with the rate constants $k$ of the OSA and thermal degradation in different solvents are given in Table 3. The thermodestruction process in the studied solvents is well described by the kinetic equation of the first order reaction rate (Fig. 5). The effective rate constants $k$ of OSA thermal decomposition were calculated from the inclination of the dependences $\ln \left(C_{0} / C_{t}\right) v s$. $t$. The values of $k$ depends on reaction medium. The highest value is observed during the reaction of OSA thermal decomposition in dioxane. The rate constant of the decomposition in ethylbenzene is more than twice as low. It is found that $S_{0}$ value is inversely proportional to $k$ value. For example, $k$ values for didecanoildiperoxyadipinate (DP) and lauryl peroxide (PL) of mono- and diperoxide analogues of OSA are given in Table 3.

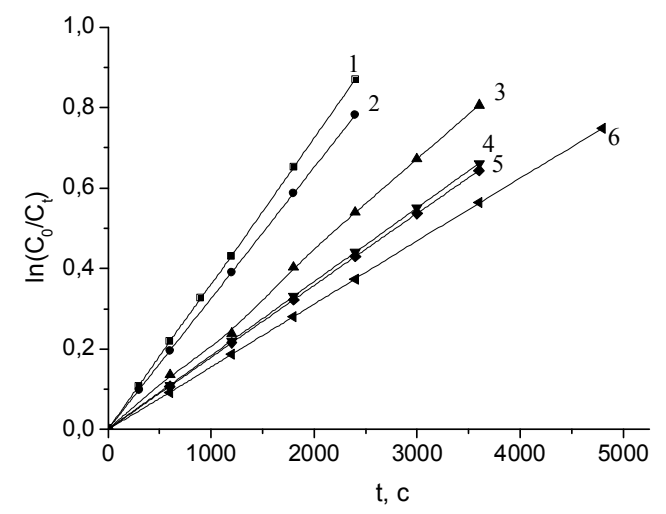

Fig. 5. Kinetetic curves of OSA thermal decomposition at $353 \mathrm{~K}$. Solvents are dioxane (1); ethylacetate (2); chlorbenzene (3); benzene (4); toluene (5) and ethylbenzene (6) 
The values of the area $S_{0}\left(\AA^{2}\right)$ corresponding to the monomeric chain of peroxide in the monolayer

\begin{tabular}{|c|c|c|c|c|c|c|c|c|c|}
\hline \multirow{2}{*}{ Solvent } & \multirow{2}{*}{ Oligoperoxide } & \multicolumn{7}{|c|}{ The values of $S_{0}$ at various concentrations of peroxide, g/dl } \\
\cline { 3 - 10 } & & 1.0 & 0.55 & 0.32 & 0.25 & 0.16 & 0.125 & 0.08 & 0.04 \\
\hline \multirow{2}{*}{ Benzene } & OPA & 5.6 & 8.6 & 11.3 & 14.0 & 15.0 & 25.3 & 42.0 & 89.5 \\
\cline { 2 - 10 } & OAA & 8.6 & 9.5 & 12.0 & 15.0 & 16.5 & 26.6 & 30.6 & 45.0 \\
\hline \multirow{2}{*}{ Chloroforme } & OPA & 7.3 & 14.5 & 15.3 & 16.3 & 17.3 & 28.6 & 49.0 & 95.0 \\
\hline & OAA & 9.0 & 15.6 & 17.6 & - & 22.3 & 31.0 & 51.0 & 54.0 \\
\hline Styrene & OAA & 7.3 & 8.6 & 11.0 & 12.6 & 16.0 & 23.0 & 33.0 & 47.3 \\
\hline
\end{tabular}

Table 3

The limit values of the areas corresponding to the chain of OSA $\left(S_{0}\right)$ and thermolysis rate constant $(k)$ of peroxides in various organic solvents at $353 \mathrm{~K}$

\begin{tabular}{|c|c|c|c|c|}
\hline \multirow{2}{*}{ Solvent } & \multirow{2}{*}{$S_{\mathrm{m}}, \AA^{2}$} & \multicolumn{3}{|c|}{$k 10^{5}, \mathrm{~s}^{-1}$} \\
\hline & & OSA & DP & PL \\
\hline Dioxane & 7.6 & 36.2 & 37.2 & 33.4 \\
\hline Acetone & 10.6 & 35.6 & 31.9 & - \\
\hline Ethylacetate & 11.0 & 32.6 & 24.7 & 26.1 \\
\hline Methylethylketone & 12.0 & - & - & - \\
\hline Chlorbenzene & 15.6 & 22.4 & 20.9 & 21.5 \\
\hline Styrene & 16.0 & 19.9 & 19.2 & - \\
\hline Benzene & 16.0 & 18.4 & 19.4 & 17.3 \\
\hline Toluene & 17.0 & 17.9 & 17.4 & 16.1 \\
\hline Ethylbenzene & 21.3 & 15.6 & 14.1 & 15.1 \\
\hline Chloroform & 22.5 & 24.6 & 24.8 & 24.4 \\
\hline
\end{tabular}

The numerical values of $k$ for DP and PL are lower than the corresponding values for OSA, which can be explained by the presence of thermal degradation of oligoperoxide intra-molecular induced decomposition. Since OSA has a oligomeric nature, this peroxide can have a different conformational state at different solvents. When oligomer peroxide from various organic solvents is transferred to the water-air phases interface, its conformational state can be stored. Thus, the values of $S_{0}$ obtained in the observed conditions will be different. The different conformational state of oligomeric peroxide will affect the total rate of the thermal decomposition. A correlation between the total constants of oligoperoxide thermal decomposition and the values of the areas corresponding to the monomer link was found.

The thermodestruction of oligomeric peroxides includes the primary homolytic disintegration and the processes of intermolecular and intra-molecular induced decomposition [27]. The numerical values of $k$ for oligomeric peroxide are more than the corresponding values of mono- or diperoxide analogues. The less is $S_{0}$ value of oligomer peroxide in the solution, the more is contribution to the effective $k$ value of the induced decomposition processes.

\section{Conclusions}

The process of oligoperoxide adsorption on the surface of aerosil and magnesium oxide is well described by the equation of Langmuir's monomolecular adsorption. The areas corresponding to the peroxide link in the adsorption layer are $61-53$ and $13.7-11.5 \AA^{2}$ for the aerosil and magnesium oxide, respectively. This feature indicates the different orientation of the oligomer peroxide in the monolayer. The thermodynamic parameters of the adsorption process for aerosil and magnesium oxide are almost the same indicating its similarity. The $\Delta G, \Delta H$ and $\Delta S$ thermodynamic parameters of the adsorption process are calculated according to the temperature dependence of adsorption-desorption equilibrium constants. Adsorption of oligomeric peroxides on aerosil and magnesium oxide occurs due to the formation of hydrogen bonds between the surface $\mathrm{OH}^{-}$groups of the adsorbent and peroxide groups. At the boundary of the phase separation the behavior of oligomeric peroxides is similar. The monolayers of the studied oligomeric peroxides belong to the condensation-type. The solvent used to apply oligoperoxide film to water-air phases interface affects the area that correspond to peroxide monomeric link. The 
oligomer nature of the studied peroxides is manifested when applied peroxide monolayer to water-air phase interface in various organic solvents. The best thermodynamic quality of the solvent results in the increase in the area of the peroxide monolayer. Due to the changes in the conformational state, the reactivity of peroxide groups of oligoperoxide is also changes.

\section{References}

[1] Voronov S., Varvarenko S.: Peroxidovmisni Makromolekuly na Mezhi Rozdilu Phaz. Lviv Polytech. Publ. House, Lviv 2011.

[2] Yaremenko I., Vil V., Demchuk D. et al.: Beilstein J. Org. Chem., 2016, 12, 1647. https://doi.org/10.3762/bjoc.12.162

[3] Antonovskii V., Khursan S.: Russ. Chem. Rev., 2003, 72, 939. https://doi.org/10.1070/RC2003v072n11ABEH000749

[4] Jiang O., Li J., Zhang D. et al.: Polym. Chem., 2017, 8, 4428. https://doi.org/10.1039/C7PY00844A

[5] Dutka V., Aksimentyeva O., Oshshapovska N. et al.: Colloid. Interface., 2019, 3, 13. https://doi.org/10.3390/colloids3010013

[6] Nedilko S.: Acta Phys. Pol. A, 2018, 133, 829.

https://doi.org/10.12693/APhysPolA.133.829

[7] Berlin A.: Polymernye Kompozitnye Materialy: Stryktura, Tehnologia. St. Petersburg 2011.

[8] Katz H., Milewski V.: Handbook of Fillers and Reinforcements for Plastics. Utility Reserch Co, Montclair Nrw Jersey, London, Toronto, Melbourne 1979.

[9] Sun W.: RSC. Adv., 2016, 6, 42084.

https://doi.org/10.1039/C6RA02607A

[10] Dutka V., Kovalskiy Ya., Dutka Yu.: Ukr. Khim. Zh., 2016, 82, 122.

[11] Dutka V.: Polymernyi Zh., 2013, 35, 134.

[12] Dutka V., Kovalskiy Ya., Dutka Yu.: Polymernyi Zh., 2014, 36, 207.

[13] Dutka V.: Polymernyi Zh., 2011, 33, 276.

[14] Dutka V.: Polymernyi Zh., 2010, 32, 166.

[15] Dutka V., Aksimentyeva O., Kovalskyi Ya., Halechko H.: XIV

Ukr. Conf. on Macromolecules. Ukraine, Kyiv 2018, 103.

[16] Ostapovich B., Hertsik O., Kovalychyn Ya.: Laboratorni Roboty z Khimii Vysokomolekularnych Spolyk. Vyd-vo Lviv. Univ., Lviv 2019.

[17] Dutka V., Midyna G., Dutka Yu., Palchikova E.: Russ. J. Gen. Chem., 2015. 85, 2703.

https://doi.org/10.1134/S1070363215120063

[18] Dutka V., Midyana G., Pal'chikova E., Dutka Yu.: Russ. J.

Gen. Chem., 2018, 88, 632.

https://doi.org/10.1134/S1070363218040047

[19] Antonovskii V., Buzulanova M.: Analitichskaya Khimia

Organicheskikh Peroksidnykh Soedinenii: Khimia, Moskva 1978.
[20] Weissberger A., Proscauer E., Riddick J., Toops E.: Technics of Organic Chemistry, vol. 7. Organic Solvents: Physical Properties and Methods of Purification. Wiley, New York 1955. [21] Gordon A., Ford R.: A Handbook of Practical Data, Techniques, and Reference. Wiley, New York 1972.

[22] Mottola M., Caruso B., Perilo M.: Sci. Rep., 2019, 9, 2259. https://doi.org/10.1038/s41598-019-38674-9

[23] Wales D., Kitchen J.: Chem. Central J., 2016, 10, 72. https://doi.org/10.1186/s13065-016-0224-6

[24] Scholl F., Coseli L.: Colloid Surface B, 2014, 126, 232. https://doi.org/10.1016/j.colsurfb.2014.12.033

[25] Bezkrovnaya O., Mchedlov-Petrosyan N., Vodolazkaya N. et al.: Russ. J. Appl. Chem., 2008, 81, 696.

https://doi.org/10.1134/S1070427208040253

[26] Roberts G. (Ed.): Langmuir Blodgett Films. Springer 2013. https://doi.org/10.1007/978-1-4899-3716-2

[27] Antonovskii V., Khursan S.: Phyzicheskaia Khimia

Organicheskykh Peroxidov. Akademkniga, Moskva 2003.

Received: April 26, 2019 / Revised: June 30, 2019 / Accepted: November 21, 2019

\section{АДСОРБЦІЯ ОЛІГОМЕРНИХ ПЕРОКСИДІВ НА АЕРОСИЛІ І ОКСИДІ МАГНІЮ ТА ЇХНЯ ПОВЕДІНКА НА МЕЖІ РОЗДІЛУ ФАЗ ВОДА - ПОВІТРЯ}

Анотація. Вивчено адсорбиію олігомерного пероксиду себачинової кислоти на аеросилах та дисперсному оксиді магнію. Знайдено параметри адсорбиійного процесу. Показано, щзо адсорбиія здійснюється внаслідок утворення водневих зв'язків поверхневих ОН- груп адсорбентів та пероксидними групами. Процес адсорбиії подібний до поведінки пероксидних сполук на межі поділу фаз вода - повітря. Вивчено особливості формування мономолекулярних плівок олігомерних пероксидів на водній поверхні. Встановлено, що числові значення площ, екстрапольовані на нульовий тиск $\left(S_{0}\right)$, залежсать від природи розчинника, який застосовували для нанесення пероксиду на межу розділу фаз. Моношари досліджуваних олігомерних пероксидів належсать до конденсованого типу. Вивчено термічний розклад олігомерного пероксиду та його дипероксидного та монопероксидного аналогів. Показано, що сумарні константи швидкості термодеструкиї $k$ для олігомерного пероксиду вищі, у порівнянні з ди- та монопероксидними аналогами. Між числовими значеннями $S_{0}$ та константами термічного розкладу $k$ олігопероксиду існує кореляційна залежність. Чим менше значення $S_{0}$, тим вище значення $k$. При перенесенні розчину олігомерного пероксиду в органічному розчиннику на межу розділу фаз конформаційний стан макромолекули зберігається, щуо впливає на чисельні значення величин $k$.

Ключові слова: олігомерні пероксиди, адсорбиія, моношар, реакиійна здатність. 